(c) Group of authors, 2016

UDC 616.316-008.8-074:[616.12-005.4:616.379-008.64]

DOI - http://dx.doi.org/10.14300/mnnc.2016.11021

ISSN 2073-8137

\title{
NON-INVASIVE MONITORING FOR LOCAL IMMUNE AND ANTIOXIDANT RESISTANCE IN PATIENTS WITH ISCHEMIC HEART DISEASE AND TYPE 2 DIABETES
}

\author{
Bykova N. I., Basov A. A., Melkonyan K. I., Alekseenko E. A., Popov K. A., Bykov I. M. \\ Kuban State Medical University, Krasnodar, Russian Federation

\section{ВОЗМОЖНОСТИ НЕИНВАЗИВНОГО МОНИТОРИНГА АОКААЬНОЙ ИММУННОЙ И АНТИОКСИААНТНОЙ РЕЗИСТЕНТНОСТИ ПАЦИЕНТОВ С ИШЕМИЧЕСКОЙ БОАЕЗНЬЮ СЕРАЦА И САХАРНЫМ АИАБЕТОМ 2 ТИПА}

\author{
Н. И. Быкова, А. А. Басов, К. И. Мелконян, Е. А. Алексеенко, К. А. Попов, И. М. Быков
}

\begin{abstract}
Кубанский ГосуАарственный МеАицинский университет, Краснолар, Российская ФеАерация
\end{abstract}

The item offers a view at the changes taking place in the immunologic responsiveness and the indices for the prooxidant-anti-oxidant system in the blood and in the oral liquid in case of T2D and IHD. There has been a significant IgA increase detected in the oral cavity in cases of T2D coming along with IHD (2.1 times), and IgM - at T2D (4 times). An imbalance has been found in the pro-oxidant-anti-oxidant system, accompanied by an increase in products of oxidative modification of biomolecules and decreased activity of catalase and superoxide dismutase in blood and oral liquid, especially in case of T2D comorbid with IHD. There has been significant correlation links established between the indices of immunologic responsiveness and the enzymes of anti-radical protection in blood and in oral liquid, as well as direct reliable correlation links between clinical indices for periodontal status and the indicators of non-specific protection in the oral cavity $(r= \pm 0,76-0,99)$.

Key words: oral liquid, diabetes mellitus, ischemic heart disease, immunoglobulin, superoxide dismutase

Представлены изменения иммунологической реактивности и показателей прооксидантно-антиоксидантной системы крови и ротовой жидкости при сахарном диабете 2 типа (СД2Т) и ишемической болезни сердца (ИБС). Отмечено выраженное увеличение в ротовой полости IgA при сочетанном течении СД 2 Т и ИБС (в 2,1 раза), a IgM - при СД2Т (в 4 раза). Выявлено развитие дисбаланса в прооксидантно-антиоксидантной системе, сопровождающееся повышением продуктов окислительной модификации биомолекул и снижением активности каталазы и супероксиддисмутазы в крови и ротовой жидкости, особенно при сочетанном течении СД2Т и ИБС. Установлены существенные корреляционные взаимосвязи между показателями иммунологической реактивности и ферментами антирадикальной защиты в крови и ротовой жидкости, а также достоверные прямые корреляционные взаимосвязи между клиническими индексами состояния пародонта и показателями системы неспецифической защиты ротовой полости ( $r= \pm 0,76-0,99)$.

Ключевые слова: ротовая жидкость, сахарный диабет, ишемическая болезнь сердца, иммуноглобулин, супероксиддисмутаза

D isturbed functioning in the pro-oxidant-antioxidant system results, under many ailments, in intensification of free-radical oxidation (FRO) and the development of oxidation stress (OS), which in case of cardiovascular pathologies account for one of the leading causes of delayed complications [2, 3 , $10,12]$. The recent years have witnessed an increase in the interest taken in the development of newer non-invasive algorithms using oral liquid to evaluate the status of the anti-oxidant system (AOS) in case of dental and other issues $[1,4,17]$.

A number of research projects reveal a close link between disturbed FRO and the immune system status $[11,15,16]$. Along with evaluating specific elements of immunity, of interest is also investigation of lacto- ferrin levels, which is not only one of the major factors for non-specific protection system yet also modulates immune processes. Lactoferrin suppresses the expression of certain pro-inflammatory - interferon- $\gamma$, interleukin-1b, tumor necrosis factor alpha, interleukin-6 [5,9,13], and anti-inflammatory (interleukins 4 \& 10) cytokines [16]. Besides, lactoferrin promotes the development of superoxide anion radical and NO, as well as the production of pro-inflammatory interleukin $8[14,15]$.

The aim of this work was to study the interconnection between the indices of immunologic responsiveness and the AOS status in blood and in oral liquid in patients with ischemic heart disease (IHD) and Type 2 diabetes (T2D). 
Material and Methods. The biological material used for the study included blood and oral liquid in patients with T2D (Group 1, $n=25$, average duration of disease $8.9 \pm 1.1 \mathrm{yrs}$, mean age $60.3 \pm 2.9$ ), IHD (Group $2, n=25$, average duration of disease $9.3 \pm 0.9 \mathrm{yrs}$, mean age $77.4 \pm 2.0$ ) and cases of IHD along with T2D (Group $3, n=25$, average duration of diseases $14.1 \pm 1.3 \mathrm{yrs}$, mean age $65.9 \pm 2.1$ ), while the control group included 25 people (Group 4, mean age $64.7 \pm 11.5$ ).

The selection and check-up of the patients was carried out on the premises of Cardiology Ward of Prof. Krasovitov Regional Clinical Hospital № 1, Endocrinology Ward of Prof. Ochapovsky Regional Clinical Hospital, Regional Counseling Polyclinic, Polyclinic № 7 of City of Krasnodar.

The status of the periodontal tissues was evaluated using clinical indices, which was done in order to improve the general reliability of the findings [4]. The periodontal status was scored in points employing the Periodontal disease index of Russell (PI - A. Russel, 1956) and the papillary marginal alveolar index (PMA, \%), where the gum around each tooth is stained following Schiller-Pisarev's test.

The activity levels for anti-radical enzymes of the first-line protection (SOD) was detected based on the SOD capacity to inhibit quercetin auto-oxidation due to dismutation of superoxide anion radical that develops at quercetin oxidation in the presence of $\mathrm{N}, \mathrm{N}, \mathrm{N}_{1}, \mathrm{~N}_{1}$-tetramethylethylenediamine under aerobic conditions [8]. The SOD specific activity was expressed in standard units in relation to $1 \mathrm{~g}$ protein of oral liquid or hemoglobin. The catalase (CAT) activity was detected via the colorimetric method [7], based on the hydrogen dioxide not destroyed by the enzyme. The enzyme activity was expressed in $\mu \mathrm{mol} /$ (min $\times \mathrm{g}$ of protein) for oral liquid or $\mu \mathrm{mol} /(\min \times \mathrm{g} \mathrm{Hb})$ for blood plasma.

The identification of human immunoglobulins $A$, $G$ and $M(\lg A, \lg G$ and $\lg M)$ [11] and lactoferrin in oral liquid and blood [14] was carried out through enzyme immunoassay.

The identification of products from oxidation modification of biomolecules was carried out based on quantitative evaluation of the stained complex developing through interaction between secondary products of oxidation modification (predominantly malondialdehyde), to be found in the oral liquid and blood plasma, and thiobarbituric acid (TBA). The outcomes were expressed in $\mu$ moles of TBA-reactive products (TBA-RP) per $1 \mathrm{~L}$ of oral liquid or blood plasma [6].

The statistical processing of the obtained data was performed with variation statistics methods employing the Student's t-test. The difference was considered statistically meaningful at $p<0.05$. Pearson's coefficient $(r)$ was used to evaluate the correlation interconnections of certain parameters under study.

Results and Discussion. The study has shown that the patients with IHD and T2D revealed prominent changes in the clinical indices reflecting the periodontal status (Table). There were prominent inflammation-dystrophic processes identified. The PI, which allows detecting the prevalence and the intensity of gum tissue lesion proved rather high in Group 3 and was above that of Group 1 by $4.9 \%$, Group 2 - by $67.9 \%$, while exceeding the control Group's (4) indices 18.4 times $(p<0.05)$. The PMA index was basically no different in Groups 1 and 3, yet exceeded the same index of Group 2 by $11.6 \%$, and was significantly above that in the control Group.
Table 1

Values for periodontal status, immunologic reactivity, and functioning of pro-oxidant-anti-oxidant system in blood and in oral liquid in patients with IHD and Type 2 diabetes $(\mathrm{M} \pm \mathrm{m})$

\begin{tabular}{|c|c|c|c|c|}
\hline Index & Group 1 & Group 2 & Group 3 & Group 4 \\
\hline PMA & $54.86 \pm 3.09 *$ & $49.14 \pm 3.62 *$ & $53.61 \pm 4.95^{*}$ & $9.74 \pm 1.82$ \\
\hline $\mathrm{PI}$ & $.69 \pm 0.74 *$ & $4.18 \pm 0.35^{*}$ & $7.02 \pm 0.51 *$ & $0.38 \pm 0.17$ \\
\hline Index & \multicolumn{4}{|c|}{ Blood } \\
\hline $\operatorname{Ig} A$ & $1.52 \pm 0.13^{*}$ & $1.99 \pm 0.12^{*}$ & $2.50 \pm 0.19 *$ & $0.90 \pm 0.08$ \\
\hline IgM & $1.17 \pm 0.14$ & $0.86 \pm 0.09$ & $1.19 \pm 0.09$ & $1.00 \pm 0.08$ \\
\hline IgG & $4.90 \pm 0.30$ & $4.85 \pm 0.36 *$ & $4.00 \pm 0.32$ & $3.79 \pm 0.33$ \\
\hline $\begin{array}{l}\text { Lacto- } \\
\text { ferrin }\end{array}$ & $\begin{array}{c}394.34 \\
\pm 19.17^{*} \\
\end{array}$ & $\begin{array}{c}404.33 \\
\pm 21.11^{*} \\
\end{array}$ & $\begin{array}{c}718.75 \\
\pm 32.25^{*} \\
\end{array}$ & $\begin{array}{l}571.40 \\
\pm 31.27 \\
\end{array}$ \\
\hline SOD & $13.29 \pm 0.64 *$ & $16.45 \pm 0.86 *$ & $11.72 \pm 0.51 *$ & $24.19 \pm 1.31$ \\
\hline CAT & $41.30 \pm 0.94 *$ & $49.02 \pm 1.37^{*}$ & $35.66 \pm 1.03 *$ & $70.63 \pm 1.65$ \\
\hline $\begin{array}{l}\text { TBA- } \\
\text { RP } \\
\end{array}$ & $6.87 \pm 0.12 *$ & $5.52 \pm 0.37 *$ & $9.13 \pm 0.43 *$ & $2.35 \pm 0.06$ \\
\hline Index & \multicolumn{4}{|c|}{ Oral liquid } \\
\hline sIgA & $0.26 \pm 0.04$ & $0.19 \pm 0.03$ & $0.35 \pm 0.05^{*}$ & $0.17 \pm 0.02$ \\
\hline IgM & $\begin{array}{c}0.012 \\
\pm 0.001 * \\
\end{array}$ & $\begin{array}{c}0.009 \\
\pm 0.001 * \\
\end{array}$ & $\begin{array}{c}0.011 \\
\pm 0.001 * \\
\end{array}$ & $\begin{array}{c}0.003 \\
\pm 0.0015 \\
\end{array}$ \\
\hline IgG & $0.20 \pm 0.02$ & $0.20 \pm 0.02$ & $0.20 \pm 0.01$ & $0.19 \pm 0.01$ \\
\hline $\begin{array}{l}\text { Lac- } \\
\text { tofer- } \\
\text { rin }\end{array}$ & $\begin{array}{c}1675.29 \\
\pm 123.12^{*}\end{array}$ & $\begin{array}{c}1741.06 \\
\pm 109.43^{*}\end{array}$ & $\begin{array}{l}1868.58 \\
\pm 98.32 *\end{array}$ & $\begin{array}{c}1410.75 \\
\pm 98.43\end{array}$ \\
\hline SOD & $13.48 \pm 0.45^{*}$ & $15.98 \pm 0.71 *$ & $12.19 \pm 0.52 *$ & $23.36 \pm 1.43$ \\
\hline CAT & $41.67 \pm 0.92 *$ & $50.72 \pm 1.06 *$ & $32.86 \pm 0.93^{*}$ & $65.29 \pm 1.51$ \\
\hline $\begin{array}{l}\text { TBA- } \\
\text { RP }\end{array}$ & $1.93 \pm 0.07 *$ & $1.09 \pm 0.10 *$ & $2.71 \pm 0.14^{*}$ & $0.62 \pm 0.08$ \\
\hline
\end{tabular}

${ }^{\star} p<0.05$ compared with the indices in the control Group 4.

The evaluation of the major Ig's in blood serum showed the presence of the most prominent changes in the IgA concentration, which was significantly above the control level in all the clinical groups with a maximum level $(2.8$ times, $p<0.05)$ registered in the patients of Group 3 whereas the minimal increase $(1.7$ times, $p<0.05)$ was detected in Group 2. Study of the oral liquid showed lack of prominent changes in the IgG levels. Locally, the most significant changes are related to $\lg \mathrm{M}$, the levels of which were significantly above the control indices: in Group 1 4 times; in Group 3 -3.6 times, and in Group 2 -3 times, and was in significant correlation with the clinical indices of the periodontal status: $r_{\mathrm{IgM} /(\mathrm{PMA}, \mathrm{PI})}=0.99^{*}, 0.98^{*}$, respectively $\left({ }^{*}-p<0.05\right)$. The levels of Ig $A$ and $M$ correlated in the blood and in the oral liquid of the patients from the groups under study: $r(\lg A)=0.76, r(\lg M)=0.50$, which proves that oral liquid can be reasonably used to evaluate the immune misbalance at such nosologies.

When studying the AOS indices in blood there was detected a decrease in the activity of the major anti-radical protection enzymes: the CAT activity was reduced in Group 1 - by $41.6 \%$ ( $<<0.05)$, Group 2 - by $30.6 \%$ $(p<0.05)$, Group 3 - by $49.5 \%(p<0.05)$. This means a higher risk of hydrogen peroxide change to a toxic free hydroxyl radical, which can initiate peroxide modification of biomolecules followed with cytolysis. During that, even more prominent was the reduction in the SOD activity, which dropped in all the experimental groups as well, and which serves proof to disturbed deactivation of superoxide anion radical, whilst the latter is one of the key oxidation factors. The oral liquid also revealed some reduction in the CAT and SOD activity, yet to a lower degree compared to the blood of the patients who went through the check-up, which is indicative of the oral cavity having its internal local AOS that allows autonomous regulation of FRO intensity through anti-radical enzymes. 
The study revealed the highest reverse correlation between the clinical indices and the activity of theanti-radical enzymes of the first (SOD) and the second (CAT) lines of protection: $r_{S O D} /(\mathrm{PMA}, \mathrm{PI})=-0.97^{*}$ and $-0.99^{*}$ respectively $\left({ }^{*}-p<0.05\right), r_{\mathrm{CAT} /(\mathrm{PMA}, \mathrm{PI})}=-0.89^{*}$ and $-0.97^{*}$ respectively $\left({ }^{*}-p<0.05\right)$. The obtained outcomes indicate the leading role of the enzymes in regulating the utilization of active oxygen forms, both in implementing local protection mechanisms at OS that prevent delayed complications following IHD and Type 2 diabetes, and in maintaining the auxiliary reactions in the local immunity.

Increased lactoferrin levels were less prominent in the oral cavity compared to their fluctuations in blood in cases of IHD and T2D. The nature of the changes taking place in the lactoferrin in the oral liquid of patients from the clinical groups generally indicates excessive production of superoxide anion radical at inflammatory lesion of periodont under reduced activity of SOD in the oral liquid and the clinical value of the reactive oxygen species involvement in the development of delayed dental complications in patients with IHD and Type 2 diabetes.

Conclusions. Disturbed local production of humoral protection factors at IHD and T2D at the local and the systemic levels are mostly due to prominent increase in the production of $\lg \mathrm{A}$ and $\lg \mathrm{M}$ in the oral liquid, while their study revealed a reliable direct correlation with similar indices in blood and the clinical indices for the periodontal status.

The development of imbalance in the functioning of pro-oxidant-anti-oxidant system linked with reduced activity in the AOS enzyme chain in oral liquid and in blood (SOD, CAT) results in significant OS, leads to lesion in the periodontal tissues, and points at need for measures aimed at improving anti-oxidant potential in the oral liquid.

The changes of certain indices registered in the oral liquid in some cases (IgM, SIgA, LF, SOD) is of higher diagnostic importance in case of IHD and Type 2 diabetes than detecting similar values in blood, which allows conducting non-invasive monitoring and evaluating the efficiency of the respective therapeutic measures in the outpatient setting.

Acknowledgements. The research work was carried out as part of the Public Task from Ministry of Healthcare of Russian Federation (of 28/01/2015, Part 1, Chapter 1) for Applied Scientific Research including Pre-Clinical Study of Medications and Clinical Study of Medicines.

\section{References}

1. Ben-Zvi I., Green Y., Nakhoul F. Effects of diabetes mellitus, chronic renal failure and hemodialysis on serum and salivary antioxidant status. Nephron Clin. Pract. 2007:105:114-120.

2. Dedov I. I., Shestakova M. V. Saharnyj diabet v pozhilom vozraste: diagnostika, klinika, lechenie. Prakticheskoe rukovodstvo dlja vrachej. M.; 2011. $90 \mathrm{p}$

3. Garcia-Caballero M., Tinahones F. J., Cohen R. V. Diabetes surgery. 1st ed. - Madrid:«McGraw Hill»; 2010.

4. Grigor'jan A. S., Grudjanov A. I., Rabuhina H. A., Frolova O. A. Bolezni parodonta: patogenez, diagnostika, lechenie. M.; 2004. 320 p.

5. Guillen C., Mclnnes I. B., Vaughan D. M., Kommajosyula S., Van Berkel P. H., Leung B. P. Enhanced Th1 response to Staphylococcus aureus infection in human lactoferrin transgenic mice. J. Immunol. 2002;168:3950-3957.

6. Kamyshnikov V. S. Spravochnik po kliniko-biohimicheskim issledovanijam i laboratornoj diagnostike. M.: «MEDpress-inform»; 2004. 920 p.

7. Koroljuk M. A., Ivanov L. I., Majorova I. G., Tokarev V. P. Metod opredeleniya aktivnosti katalazi. Laboratornoe delo. - Laboratory business. 1988;1:16-19.

8. Kostjuk V. A., Potapovich A. I., Kovaleva Zh. I. Prostoi i chuvstvitelniy metod opredeleniya superoksiddismutazi. Voprosy medicinskoj himii. - Problems of medical chemistry. 1990;2:88-91.

9. Kruzel M. L., Harari Y., Mailman D., Actor J. K., Zimecki M. Differential effects of prophylactic, concurrent and therapeutic lactoferrin treatment on LPS-induced inflamatory responses in mice. Clin. Exp. Immunol. 2002; 130:25-31.

10. Laihia J. K., Jansen C. T., Ahotupa M. Lucigenin and linoleate enhanced chemiluminescent assay for superoxide dismutase activity. Free Radic. Biol. and Med. 1993:14:457-461.

11. Mancini G., Carbonara A., Heremans G. Immunological quantitation of antigens by single radial immunodiffusion. Immunochemistry. 1965;2(3):235-254.

12. Mayer-Davis E.J. Type 2 diabetes in youth: epidemiology and current research toward prevention and treatment. J. Am. Diet. Assoc. 2008;108(4,1):S45-S51.

13. Sawatzki G. Rich I. N. Lactoferrin stimulates colony stimulating factor production in vitro and in vivo. Blood Cells. 1989;15:371-385.

14. Shinoda I., Takase M., Fukuwatari Y., Shimamura S. Koller M. Konig W. Effects of lactoferrin and lactoferricin on the release of interleukin 8 from human polymorphonuclear leukocytes. Biosci. Biotechnol. Biochem. 1996;60:521-523.

15. Sorimachi K., Akimoto K., Hattori Y., Leiri T., Niwa A. Activation of macrophages by lactoferrin: secretion of TNF-a, IL-8 and NO. Biochem. Mol. Biol. Int. 1997;43:7987.

16. Togawa J., Nagase H., Tanaka K., Inamori M., Nakajima A Ueno N. Oral administration of lactoferrin reduces colitis in rats via modulation of the immune system and correction of cytokine imbalance. J. Gastroenterol. Hepatol. 2002;17:1291-1298

17. Volozhin A I. Stomatologija novogo tysjacheletija: Sb tezisov. M.:«Aviaizdat»; 2002.

\section{About authors:}

Bykova Natalia, MD, Associate Professor; Department of Child Dentistry, Orthodontics and Maxillofacial Surgery; tel.: +79181487866; e-mail: bikov_mi@mail.ru

Basov Alexander, MD, Associate Professor; Department of Fundamental and Clinical Biochemistry; tel.: +79183551302; e-mail: son_sunytch@mail.ru

Melkonyan Karina, MD, Assistant Lecturer; Department of Fundamental and Clinical Biochemistry; tel.: +79183422323; e-mail: agaron@list.ru Alekseenko Elena, Chief Medical Officer, Municipal Healthcare Institution POLYCLINIC № 26; tel.: +79184893381; e-mail: ilya.bh@mail.ru Popov Konstantin, Post-graduate student; Department of Fundamental and Clinical Biochemistry; tel.: +79288824941; e-mail: naftalin444@mail.ru

Bykov Ilya, MD, PhD, Professor, Head of Department of Fundamental and Clinical Biochemistry; tel.: +79182125530; e-mail: ilyamb@ksma.ru 